\title{
Anti-angiogenic effects of biotechnological therapies in rheumatic diseases
}

This article was published in the following Dove Press journal: Biologics:Targets and Therapy

\author{
Francesco Paolo Cantatore \\ Nicola Maruotti' \\ Addolorata Corrado' \\ Domenico Ribatti ${ }^{2,3}$ \\ 'Rheumatology Clinic, Department \\ of Medical and Surgical Sciences, \\ University of Foggia Medical School, \\ Foggia, ${ }^{2}$ Department of Basic Medical \\ Sciences, Neurosciences and Sensory \\ Organs, University of Bari Medical \\ School, ${ }^{3}$ National Cancer Institute \\ "Giovanni Paolo II", Bari, Italy
}

Correspondence: Francesco Paolo Cantatore

Rheumatology Clinic "Mario Carrozzo", "Ospedali Riuniti” Hospital,

Viale Pinto, I, I-7I I00 Foggia, Italy

Tel $+390881733 \quad 64$

Email francescopaolo.cantatore@unifg.it
Introduction: Angiogenesis plays a key role in the pathogenesis of numerous rheumatic diseases, such as rheumatoid arthritis, psoriatic arthritis, and vasculitides. Therefore, the inhibition of pathological angiogenesis may be considered a useful therapeutical approach in these rheumatic diseases.

Methods: This review article is based on a literature research about the role of biotechnological therapies in angiogenesis inhibition.

Results and conclusions: Several evidences have demonstrated a role for biotechnological therapies in angiogenesis inhibition. Nevertheless, further research and clinical trials are needed to better quantify the real impact of biotechnological therapies on pathological angiogenesis.

Keywords: abatacept, anakinra, angiogenesis, rituximab, TNF- $\alpha$, tocilizumab

\section{Introduction}

Angiogenesis dysregulation is emerging as a key player in numerous rheumatic diseases, such as chronic arthritides, connective tissue diseases, and vasculitides. ${ }^{1-3}$ In fact, a dysregulation of both angiogenic and anti-angiogenic factors has been seen in synovial tissues and sera of patients affected by chronic arthritides, such as rheumatoid arthritis (RA) and psoriatic arthritis (PsA). ${ }^{4,5}$ Moreover, angiogenesis may be involved in the pathogenesis of vasculitides, as the consequence of ischemia and intense metabolic activity, which may characterize these diseases. ${ }^{3}$ In this review, we want to focalize the current knowledge in angiogenesis occurring in rheumatic diseases about the role of biotechnological therapies, which represent important therapeutic arms in many of these diseases.

In synovitis pathogenesis, the production of angiogenic factors is responsible for the activation of endothelial cells. Activated endothelial cells produce proteolytic enzymes such as matrix metalloproteinases (MMPs) and plasminogen activators, which are involved in the degradation of the basement membrane and of the perivascular extracellular matrix. The subsequent endothelial cell proliferation and migration into the perivascular area lead to the formation of "primary sprouts" forming "capillary loops." The proliferation of endothelial cells of these "primary sprouts" and their migration is then responsible for the generation of secondary and further generations of vascular sprouts. ${ }^{6}$ The balance between angiogenic and anti-angiogenic factors is responsible for the regulation of these events. ${ }^{7}$

The main factors involved in angiogenesis stimulation are vascular endothelial growth factor (VEGF), platelet-derived growth factor, fibroblast growth factor (FGF), 
transforming growth factor (TGF)- $\alpha$ and $-\beta$, tumor necrosis factor- $\alpha$ (TNF- $\alpha$ ), interleukins (ILs), chemokines, angiogenin, and angiopoietins. Conversely, the action of these factors is counteracted by anti-angiogenic agents, such as endostatin, angiostatin, and thrombospondin. An imbalance between these angiogenic and anti-angiogenic factors is responsible for angiogenesis dysregulation. ${ }^{1-3}$

In RA and PsA, the predominance of these angiogenic agents over the anti-angiogenic agents triggers angiogenesis. ${ }^{4,8,9}$ Different morphological vascular alterations have been described in RA and in PsA synovial tissues. In fact, RA is usually characterized by straight vessels with regular branching, while PsA is generally characterized by tortuous, bushy, elongated vessels, suggesting the presence of different angiogenic pathways between PsA and RA. ${ }^{10}$

Regarding connective tissue diseases, such as systemic lupus erythematosus (SLE), angiogenic factors including VEGF, endothelial growth factor (EGF), FGF, and IL-18, as well as angiostatic factors, such as endostatin, have been found in sera of patients. ${ }^{11,12}$ Zhou et al ${ }^{13}$ have found higher levels of placental growth factor, basic FGF (bFGF), and VEGF in SLE patients than in normal controls, suggesting a role for these angiogenic factors in SLE pathogenesis.

In vasculitides, high levels of VEGF and TGF- $\beta$ have been described in Kawasaki syndrome and in antineutrophil cytoplasmatic antibody (ANCA)-associated vasculitides. ${ }^{11,12,14}$ In vasculitides, stenosis or occlusion of the vascular lumen induce hypoxia which is a potent signal for angiogenesis. Thus, angiogenesis may be a compensatory response to hypoxia and to the increased metabolic activity due to inflammation. ${ }^{3}$

\section{Biotechnological therapies}

Biotechnological therapies play a key role in the treatment of several rheumatic diseases, such as RA, PsA, ankylosing spondylitis, SLE, Wegener granulomatosis, and microscopic polyangiitis (MPA). To date, the available biotechnological therapies are TNF- $\alpha$ inhibitors (infliximab, adalimumab, etanercept, golimumab, and certolizumab), anti-IL-1 receptors (anakinra), anti-IL-6 receptors (tocilizumab), antiIL-17 antibodies (secukinumab), anti-IL-12/23 antibodies (ustekinumab), anti-CD-20 antibodies (rituximab), antiB-cell activating factor (belimumab), and anti-CD80 and anti-CD86 receptors (abatacept) (Table 1).

There are accumulating evidences of the role of these agents in angiogenesis inhibition. In consideration of the role of angiogenesis in rheumatic diseases, angiogenesis inhibition may represent a useful therapeutic arm against these diseases, and in particular against chronic arthritis.

\section{TNF- $\alpha$ inhibitors}

TNF- $\alpha$ plays a key role in inducing the expression of important angiogenic factors, such as VEGF, angiopoietin-1 (Ang-1) and Ang-2. ${ }^{15}$ Supporting the evidence that TNF- $\alpha$ is involved in inducing angiogenesis, several studies have demonstrated that anti-TNF- $\alpha$ agents may be responsible for anti-angiogenic effects. Adalimumab has been success-

Table I Mechanisms of action of biothecnological drugs and their role in angiogenesis in rheumatic diseases

\begin{tabular}{|c|c|c|c|}
\hline Biological drug & Mechanism of action & Role in angiogenesis in rheumatic diseases & References \\
\hline Infliximab & TNF- $\alpha$ inhibition & Reduction of serum VEGF levels in RA & $33-36$ \\
\hline Adalimumab & TNF- $\alpha$ inhibition & Not studied & \\
\hline Etanercept & TNF- $\alpha$ inhibition & Not studied & \\
\hline Golimumab & TNF- $\alpha$ inhibition & Not studied & \\
\hline Certolizumab & TNF- $\alpha$ inhibition & Not studied & \\
\hline Tocilizumab & Inhibition of IL- 6 by binding to IL- 6 receptor & $\begin{array}{l}\text { Angiogenesis inhibition in synovial tissues } \\
\text { obtained from RA patients }\end{array}$ & 40 \\
\hline Abatacept & $\begin{array}{l}\text { Inhibition of T-cell activation by blocking interaction of } \\
\text { CD80/CD86 receptors to CD28 }\end{array}$ & $\begin{array}{l}\text { Reduction of serum levels of ADAMI7 and } \\
C X 3 C L I \text { in RA. Reduction of CX3CLI in RA } \\
\text { synovial fluids }\end{array}$ & 13,44 \\
\hline Rituximab & Depletion of B cell by binding to the CD20 antigen & $\begin{array}{l}\text { Reduction of serum levels of MMP-I, MMP-3, } \\
\text { MMP-9, thrombomodulin, P-selectin, and VEGF } \\
\text { in ANCA-associated vasculitis }\end{array}$ & 53 \\
\hline Anakinra & Inhibition of IL-I by binding to IL-I receptor & $\begin{array}{l}\text { Angiogenesis inhibition (evaluated only in animal } \\
\text { models of arthritis) }\end{array}$ & 58 \\
\hline Belimumab & BAFF inhibition & Not studied & \\
\hline Secukinumab & IL-I7 inhibition & Not studied & \\
\hline Ustekinumab & IL-I 2 and IL-23 inhibition & Not studied & \\
\hline
\end{tabular}

Abbreviations: ANCA, antineutrophil cytoplasmatic antibody; BAFF, B-cell activating factor; CTLA-4, cytotoxic T-lymphocyte antigen 4; IL, interleukin; MMP, matrix metalloproteinase; RA, rheumatoid arthritis; TNF- $\alpha$, tumor necrosis factor- $\alpha$; VEGF, vascular endothelial growth factor. 
fully used in neovascular age-related macular degeneration refractory to anti-VEGF therapy. ${ }^{16}$ Numerous studies by using animal models have demonstrated the efficacy of topical application of infliximab in the treatment of corneal neovascularization.${ }^{17-20}$ Moreover, golimumab has significantly inhibited angiogenesis and growth in vivo in tetratricopeptide repeats 2 (IFIT2)-depleted metastatic oral squamous cell carcinoma cells. ${ }^{21}$ In vitro, certolizumab pegol has shown an inhibitory role on TNF- $\alpha$-dependent leukocyte adhesion and angiogenesis, probably via inhibition of angiogenic adhesion molecule expression and angiogenic chemokine secretion, as demonstrated by the significant inhibition on human dermal microvascular endothelial cell surface of TNF$\alpha$-induced E-selectin, vascular cell adhesion molecule-1, and intercellular adhesion molecule-1 (ICAM-1) expression and angiogenic chemokine secretion. ${ }^{22}$

Anti-TNF- $\alpha$ agents have also demonstrated antiangiogenic effects in chronic inflammatory diseases such as psoriasis and Crohn's disease. ${ }^{23,24}$ By using in vitro and in vivo models, Liu et $\mathrm{a}^{25}$ have proposed a dual mechanism to explain the anti-psoriatic effect of IBI303, an anti-TNF- $\alpha$ monoclonal antibody, based on the inhibition of both inflammation and angiogenesis, with a direct inhibition of the anti-TNF- $\alpha$ agent on blood vessel formation in vitro. Among rheumatic diseases, anti-TNF- $\alpha$ agents have shown anti-angiogenic properties in RA and PsA. Numerous evidences confirm that VEGF plays a key role in angiogenesis occurring in arthritic synovial tissue. ${ }^{26-28}$ High VEGF serum levels have been seen in patients with inflammatory arthritis. ${ }^{29}$ Moreover, in arthritic joints, synovial lining cells, macrophages and fibroblasts surrounding microvessels, and vascular smooth-muscle cells are involved in VEGF production. ${ }^{30-32}$ In patients with active RA, a decrease in serum VEGF levels was found after infliximab treatment. ${ }^{33,34}$ Serum VEGF levels obtained by RA patients after 1 week from a single intravenously infusion of infliximab (receiving either 1 or $10 \mathrm{mg} / \mathrm{kg}$ ) were significantly reduced and remained below preinfusion levels until 2 weeks in patients treated with $1 \mathrm{mg} / \mathrm{kg}$ infliximab and 4 weeks in patients who received $10 \mathrm{mg} / \mathrm{kg}$ infliximab. ${ }^{33}$ Moreover, treatment with infliximab significantly decreased serum VEGF levels after 2 weeks in RA patients. ${ }^{34}$

TNF- $\alpha$ inhibitors have also been involved in inducing the reduction of VEGF levels in sera of patients affected by PsA. ${ }^{35,36}$ In fact, the treatment with $5 \mathrm{mg} / \mathrm{kg}$ infliximab at 0 , 2 , and 6 weeks and every 12 weeks was correlated to a significant reduction of serum VEGF levels in PsA patients. ${ }^{35,36}$

Moreover, immunohistochemical studies on synovial and psoriatic lesional skin biopsies obtained from PsA patients treated with anti-TNF- $\alpha$ agents have demonstrated reduced angiogenesis and deactivation of the endothelium, which were responsible for reduced cell infiltration and clinical improvement in psoriasis and PsA. ${ }^{37}$ A considerable fraction of new immature blood vessels has been found in synovial arthroscopic biopsies obtained from RA patients. An increment of the presence and density of immature but not mature vessels has been observed by following these patients during the progression of their disease. Moreover, only immature vessels were depleted in response to anti-TNF- $\alpha$ therapy. ${ }^{38}$

\section{Tocilizumab}

IL-6 is an important regulator of immune and inflammatory responses. It also plays a key role in angiogenesis in several diseases. ${ }^{3,9}$ Thus, it is conceivable that IL-6 inhibition may be responsible for anti-angiogenic effects.

Increased IL-6 mRNA and protein levels have been found in human oral squamous cell carcinoma. Tocilizumab treatment was correlated with significantly decreased VEGF mRNA expression in cultures of human oral squamous cell carcinoma cells. Moreover, tocilizumab treatment was also involved in reducing microvessel density and vessel diameter in a human oral squamous cell carcinoma mouse xenograft model. ${ }^{39}$

With regard to rheumatic diseases, tocilizumab treatment has been correlated to reduced angiogenesis in synovial tissues obtained from RA patients. ${ }^{40}$

\section{Abatacept}

Abatacept is a fusion protein that is responsible for the molecular interaction between antigen-presenting cells and $\mathrm{T}$ lymphocytes. It inhibits T-cell activation by blocking the interaction of CD80/CD86 receptors to CD28. T-cell inibition is then responsible for inhibiting B-cell immunological response and for a reduction of serum levels of inflammatory and angiogenic cytokines, such as TNF- $\alpha$ and IL- $6 .{ }^{41}$ Antiangiogenic effects of abatacept have been first described in 2001 in murine tumor models. ${ }^{42}$ In vitro, abatacept administration to endothelial cells was correlated to the reduction of VEGFreceptor 2 and ICAM-1, both relevant for angiogenesis. ${ }^{43}$ More recently, abatacept treatment has been correlated to the reduction of serum levels of ADAM17 and CX3CL1 in patients with RA after 24 weeks of treatment. ${ }^{44}$ High level of ADAM17 expression was found in synovial tissue and also in cartilage in patients with RA, ${ }^{45-47}$ suggesting that dysregulated ADAM17 activity and production may be involved in RA pathogenesis. ADAM17, also known as TNF- $\alpha$ converting enzyme, is a disintegrin and metalloprotease 17 , which plays a role in tissue destruction, inflammation, and angiogenesis. It is responsible for the physiological cleavage of membrane-anchored cytokines, such as CX3CL1 and 
TNF $\alpha$, releasing them in a soluble form. ${ }^{48-50}$ ADAM17 was also involved in inducing the solubilization of TNF and IL-6 receptors. ${ }^{51,52}$ CX3CL1 is expressed on cytokine-activated endothelia and induces angiogenesis both in vitro and in vivo. Immunodepletion of CX3CL1 in rheumatoid synovial fluids reduces its chemoattractant effects on endothelial cells. ${ }^{13}$

\section{Rituximab and other biotechnological drugs}

The role of rituximab in angiogenesis is still unclear, and only limited literature data are available. A reduction of markers of vascular injury and angiogenesis, such as serum levels of MMP-1, MMP-3, MMP-9, thrombomodulin, P-selectin, and VEGF, has been observed in patients affected by active ANCA-associated vasculitis who were treated with rituximab. ${ }^{53}$ Moreover, hypoxia-inducible factor- $1 \alpha$ expression has been correlated to a more favorable prognosis in patients affected by diffuse large B-cell lymphoma treated with rituximab. ${ }^{54}$

IL-1 is involved in inducing angiogenesis mainly via stimulation of VEGF production. ${ }^{55}$ The involvement of IL-1 in promoting angiogenesis makes it an interesting target for therapeutic intervention. Even if further studies are needed to better clarify this aspect, there are some studies that indicate a role for anakinra in reducing pathological angiogenesis in tumors. In fact, IL-1 also plays a role in growth and metastasization of several types of human cancers. Anakinra has shown inhibitory effects on human cancer xenografts growth in IL1-producing tumors even if no direct antiproliferative effects were found in vitro. ${ }^{56} \mathrm{~A}$ role for anakinra, when combined with the inhibition of TGF- $\beta$ and CXC receptors (CXCR) $1 / 2$ ligands, has been hypothesized in reducing in vivo resistance of tumors to antiangiogenic therapies, by using murine tumor models resistant to the anti-VEGF antibody bevacizumab. ${ }^{57}$

Studies on animal models have shown that anakinra was responsible for suppressing neovascularization in choroidal and corneal angiogenesis and in adjuvant arthritis, an experimental model of polyarthritis. ${ }^{58,59}$ Nevertheless, no further data are present in literature about the putative antiangiogenic effects of anakinra in rheumatic diseases.

To date, there are no studies that have assessed the possible anti-angiogenic effects for belimumab, secukinumab, and ustekinumab.

\section{Concluding remarks}

Angiogenesis is emerging as a key player in the pathogenesis of numerous rheumatic diseases, such as RA, PsA, and vasculitides. Therefore, it is conceivable that the inhibition of pathological angiogenesis may be a useful therapeutical approach in these rheumatic diseases. Biotechnological therapies represent an important therapeutic arm in chronic arthritis and in some vasculitides and connective tissue diseases. Even if accumulating evidences suggest an anti-angiogenic role for these drugs, further research and clinical trials are needed to better quantify their real impact on pathological angiogenesis.

\section{Disclosure}

The authors report no conflicts of interest in this work.

\section{References}

1. Leblond A, Allanore Y, Avouac J. Targeting synovial neoangiogenesis in rheumatoid arthritis. Autoimmun Rev. 2017;16:594-601.

2. Mostmans Y, Cutolo M, Giddelo C, et al. The role of endothelial cells in the vasculopathy of systemic sclerosis: a systematic review. Autoimmun Rev. 2017;16(8):774-786

3. Maruotti N, Cantatore FP, Nico B, Vacca A, Ribatti D. Angiogenesis in vasculitides. Clin Exp Rheumatol. 2008;26:476-483.

4. Elshabrawy HA, Chen Z, Volin MV, Ravella S, Virupannavar S, Shahrara $\mathrm{S}$. The pathogenic role of angiogenesis in rheumatoid arthritis. Angiogenesis. 2015;18:433-448.

5. Yamamoto T. Angiogenic and inflammatory properties of psoriatic arthritis. ISRN Dermatol. 2013;2013:630620.

6. Risau W. Mechanisms of angiogenesis. Nature. 1997;386:671-674.

7. Pepper MS. Manipulating angiogenesis: from basic science to the bedside. Arterioscler Thromb Vasc Biol. 1997;17:605-619.

8. Maruotti N, Cantatore FP, Crivellato E, Vacca A, Ribatti D. Angiogenesis in rheumatoid arthritis. Histol Histopathol. 2006;21:557-566.

9. Cantatore FP, Maruotti N, Corrado A, Ribatti D. Angiogenesis dysregulation in psoriatic arthritis: molecular mechanisms. Biomed Res Int. 2017;2017:5312813.

10. Reece RJ, Canete JD, Parsons WJ, Emery P, Veale DJ. Distinct vascular patterns of early synovitis in psoriatic, reactive, and rheumatoid arthritis. Arthritis Rheum. 1999;42:1481-1484.

11. Szekanecz Z, Koch AE. Mechanism of disease: angiogenesis in inflammatory diseases. Nat Clin Pract Rheumatol. 2007;3:635-643.

12. Bodolay E, Koch AE, Kim J, Szegedi G, Szekanecz Z. Angiogenesis and chemokines in rheumatoid arthritis and other sistemi inflammatory rheumatic diseases. J Cell Mol Med. 2002;6:357-376.

13. Zhou L, Lu G, Shen L, Wang L, Wang M. Serum levels of three angiogenic factors in systemic lupus erythematosus and their clinical significante. Biomed Res Int. 2014;2014:627126.

14. Westphal JR, Boerbooms AMT, Schalkwijk CJM, et al. Anti-endothelial cell antibodies in sera of patients with autoimmune diseases: comparison between ELISA and FACS analysis. Clin Exp Immunol 1994;96:444 449.

15. Giraudo E, Primo L, Audero E, et al. Tumor necrosis factor- $\alpha$ regulates expression of vascular endothelial growth factor receptor-2 and of its co-receptor neuropilin-1 in human vascular endothelial cells. J Biol Chem. 1998;273:22128-22135.

16. Fernández-Vega B, Fernández-Vega Á, Rangel CM, et al. Blockade of tumor necrosis factor-alpha: a role for adalimumab in neovascular agerelated macular degeneration refractory to anti-angiogenesis therapy? Case Rep Ophthalmol. 2016;7:154-162.

17. Kim JW, Chung SK. The effect of topical infliximab on corneal neovascularization in rabbits. Cornea. 2013;32:185-190.

18. Ferrari G, Bignami F, Rama P. Tumor necrosis factor- $\alpha$ inhibitors as a treatment of corneal hemangiogenesis and lymphangiogenesis. Eye Contact Lens. 2015;41:72-76.

19. Voiculescu OB, Voinea LM. Infliximab eye drops treatment in corneal neovascularization. J Med Life. 2015;8:566-567.

20. Campanati A, Orciani M, Ganzetti G, Consales V, Di Primio R, Offidani A. The effect of etanercept on vascular endothelial growth factor production by cutaneous mesenchymal stem cells from patients with psoriasis. J Int Med Res. 2016;44(1 Suppl):6-9. 
21. Lai KC, Liu CJ, Lin TJ, et al. Blocking TNF- $\alpha$ inhibits angiogenesis and growth of IFIT2-depleted metastatic oral squamous cell carcinoma cells. Cancer Lett. 2016;370:207-215.

22. Shu Q, Amin MA, Ruth JH, Campbell PL, Koch AE. Suppression of endothelial cell activity by inhibition of TNF $\alpha$. Arthritis Res Ther. 2012;14:R88.

23. Altorjay I, Veréb Z, Serfozo Z, et al. Anti-TNF-alpha antibody (infliximab) therapy supports the recovery of eNOS and VEGFR2 protein expression in endothelial cells. Int J Immunopathol Pharmacol. 2011;24:323-335.

24. Eder P, Lykowska-Szuber L, Iwanik K, et al. The influence of anti-TNF therapy on CD31 and VEGF expression in colonic mucosa of Crohn's disease patients in relation to mucosal healing. Folia Histochem Cytobiol. 2016;54:75-80.

25. Liu Y, Yang G, Zhang J, et al. Anti-TNF- $\alpha$ monoclonal antibody reverses psoriasis through dual inhibition of inflammation and angiogenesis". Int Immunopharmacol. 2015;28:731-743.

26. Paleolog EM. Angiogenesis: a critical process in the pathogenesis of RA - a role of VEGF? Br J Rheumatol. 1996;35:917-919.

27. Afuwape AO, Kiriakidis S, Paleolog EM. The role of the angiogenic molecule VEGF in the pathogenesis of rheumatoid arthritis. Histol Histopathol. 2002;17:961-972.

28. Nagashima M, Yoshino S, Ishiwata T, Asano G. Role of vascular endothelial growth factor in angiogenesis of rheumatoid arthritis J Rheumatol. 1995;22:1624-1630.

29. Ballara S, Taylor PC, Reusch P, et al. Raised serum vascular endothelial growth factor levels are associated with destructive change in inflammatory arthritis. Arthritis Rheum. 2001;44:2055-2064.

30. Kasama T, Shiozawa F, Kobayashi K, et al. Vascular endothelial growth factor expression by activated synovial leukocytes in rheumatoid arthritis. Arthritis Rheum. 2001;44:2512-2524.

31. Harada M, Mitsuyama K, Yoshida H, et al. Vascular endothelial growth factor in patients with rheumatoid arthritis. Scand J Rheumatol. 1998;27:377-380.

32. Wauke K, Nagashima M, Ishiwata T, Asano G, Yoshino S. Expression and localization of vascular endothelial growth factor-C in rheumatoid arthritis synovial tissue. J Rheumatol. 2002;29:34-38.

33. Paleolog EM, Young S, Stark AC, McCloskey RV, Feldmann M, Maini R. Modulation of angiogenic vascular endothelial growth factor by tumor necrosis factor a and interleukin-1 in rheumatoid arthritis. Arthritis Rheum. 1998;41:1258-1265.

34. Strunk J, Bundke E, Lange U. Anti-TNF-alpha antibody infliximab and glucocorticoids reduce serum vascular endothelial growth factor levels in patients with rheumatoid arthritis: a pilot study. Rheumatol Int. 2006;26:252-256.

35. Mastroianni A, Minutilli E, Mussi A, et al. Cytokine profiles during infliximab monotherapy in psoriatic arthritis. $\mathrm{Br} J$ Dermatol. 2005; 153:531-536.

36. Cordiali-Fei P, Trento E, D’Agosto G, et al. Effective therapy with anti-TNF-alpha in patients with psoriatic arthritis is associated with decreased levels of metalloproteinases and angiogenic cytokines in the sera and skin lesions. Ann NY Acad Sci. 2007;1110:578-589.

37. Goedkoop AY, Kraan MC, Picavet DI, et al. Deactivation of endothelium and reduction in angiogenesis in psoriatic skin and synovium by low dose infliximab therapy in combination with stable methotrexate therapy: a prospective single-centre study. Arthritis Res Ther. 2004;6:R326-R334.

38. Izquierdo E, Cañete JD, Celis R, et al. Immature blood vessels in rheumatoid synovium are selectively depleted in response to anti-TNF therapy. PLoS One. 2009;4:e8131.

39. Shinriki S, Jono H, Ota $\mathrm{K}$, et al. Humanized anti-interleukin-6 receptor antibody suppresses tumor angiogenesis and in vivo growth of human oral squamous cell carcinoma. Clin Cancer Res. 2009;15:5426-5434.

40. Hirohata S, Abe A, Murasawa A, Kanamono T, Tomita T, Yoshikawa H. Differential effects of IL-6 blockade tocilizumab and TNF inhibitors on angiogenesis in synovial tissues from patients with rheumatoid arthritis. Mod Rheumatol. 2016;15:1-7.
41. Herrero-Beaumont G, Martínez Calatrava MJ, Castañeda S. Abatacept mechanism of action: concordance with its clinical profile. Reumatol Clin. 2012;8:78-83.

42. Paradis TJ, Floyd E, Burkwit J, et al. The anti-tumor activity of antiCTLA-4 is mediated through its induction of IFN gamma. Cancer Immunol Immunother. 2001;50:125-133.

43. Cutolo M, Montagna P, Soldano S, et al. CTLA4-Ig/CD86 interactions in cultured human endothelial cells: effects on VEGFR-2 and ICAM1 expression. Clin Exp Rheumatol. 2015;33:250-254.

44. Umemura M, Isozaki T, Ishii S, et al. Reduction of serum ADAM17 level accompanied with decreased cytokines after abatacept therapy in patients with rheumatoid arthritis. Int J Biomed Sci. 2014;10:229-235.

45. Patel IR, Attur MG, Patel RN, et al. TNF-alpha convertase enzyme from human arthritis-affected cartilage: isolation of cDNA by differential display, expression of the active enzyme, and regulation of TNF-alpha. J Immunol. 1998;160:4570-4579.

46. Ohta S, Harigai M, Tanaka M, et al. Tumor necrosis factor-alpha (TNFalpha) converting enzyme contributes to production of TNF-alpha in synovial tissues from patients with rheumatoid arthritis. J Rheumatol. 2001;28:1756-1763.

47. Charbonneau M, Harper K, Grondin F, Pelmus M, McDonald PP, Dubois CM. Hypoxia-inducible factor mediates hypoxic and tumor necrosis factor alpha-induced increases in tumor necrosis factor-alpha converting enzyme/ADAM17 expression by synovial cells. J Biol Chem . 2007;282:33714-33724.

48. Black RA, Rauch CT, Kozlosky CJ, et al. A metalloproteinase disintegrin that releases tumour-necrosis factor-alpha from cells. Nature. 1997;385:729-733.

49. Moss ML, Jin SL, Milla ME, et al. Cloning of a disintegrin metalloproteinase that processes precursor tumour-necrosis factor-alpha. Nature. 1997;385:733-736.

50. Garton KJ, Gough PJ, Blobel CP, et al. Tumor necrosis factor-alphaconverting enzyme (ADAM17) mediates the cleavage and shedding of fractalkine (CX3CL1). J Biol Chem. 2001;276:37993-38001.

51. Peschon JJ, Slack JL, Reddy P, et al. An essential role for ectodomain shedding in mammalian development. Science. 1998;282:1281-1284.

52. Althoff K, Reddy P, Voltz N, Rose-John S, Müllberg J. Shedding of interleukin-6 receptor and tumor necrosis factor alpha. Contribution of the stalk sequence to the cleavage pattern of transmembrane proteins. Eur J Biochem. 2000;267:2624-2631.

53. Monach PA, Tomasson G, Specks U, et al. Circulating markers of vascular injury and angiogenesis in antineutrophilcytoplasmic antibodyassociated vasculitis. Arthritis Rheum. 2011;63:3988-3997.

54. Powell JR, Dojcinov S, King L, et al. Prognostic significance of hypoxia inducible factor- $1 \alpha$ and vascular endothelial growth factor expression in patients with diffuse large B-cell lymphoma treated with rituximab. Leuk Lymphoma. 2013;54:959-966.

55. Ben-Av P, Crofford LJ, Wilder RL, Hla T. Induction of vascular endothelial growth factor expression in synovial fibroblasts by prostaglandin $\mathrm{E}$ and interleukin-1: a potential mechanism for inflammatory angiogenesis. FEBS Lett. 1995;372:83-87.

56. Elaraj DM, Weinreich DM, Varghese S, et al. The role of interleukin 1 in growth and metastasis of human cancer xenografts. Clin Cancer Res. 2006;12:1088-1096.

57. Carbone C, Tamburrino A, Piro G, et al. Combined inhibition of IL1, CXCR1/2, and TGF $\beta$ signaling pathways modulates in-vivo resistance to anti-VEGF treatment. Anticancer Drugs. 2016;27:29-40.

58. Coxon A, Bolon B, Estrada J, et al. Inhibition of interleukin-1 but not tumor necrosis factor suppresses neovascularization in rat models of corneal angiogenesis and adjuvant arthritis. Arthritis Rheum. 2002;46:2604-2612.

59. Olson JL, Courtney RJ, Rouhani B, Mandava N, Dinarello CA. Intravitreal anakinra inhibits choroidal neovascular membrane growth in a rat model. Ocul Immunol Inflamm. 2009;17(3):195-200. 


\section{Publish your work in this journal}

Biologics: Targets and Therapy is an international, peer-reviewed journal focusing on the patho-physiological rationale for and clinical application of Biologic agents in the management of autoimmune diseases, cancers or other pathologies where a molecular target can be identified. This journal is indexed on PubMed Central, EMBase, and Scopus.
The manuscript management system is completely online and includes a very quick and fair peer-review system, which is all easy to use Visit http://www.dovepress.com/testimonials.php to read real quotes from published authors.

Submit your manuscript here: https://www.dovepress.com/biologics-targets-and-therapy-journal 